\title{
Recommendations for the use of Inhibited Water During Phase I Salt Dissolutions In Tank 41
}

by

P. L. Davis

Westinghouse Savannah River Company

Savannah River Site

Aiken, South Carolina 29808

not a conf

A document prepared for TANK FOCUS AREA MID-YEAR REVIEW at Salt Lake City, UT, USA from - .

DOE Contract No. DE-AC09-89SR18035

This paper was prepared in connection with work done under the above contract number with the U.S. Department of Energy. By acceptance of this paper, the publisher and/or recipient acknowledges the U.S. Government's right to retain a nonexclusive, royalty-free license in and to any copyright covering this paper, along with the right to reproduce and to authorize others to reproduce all or part of the copyrighted paper.

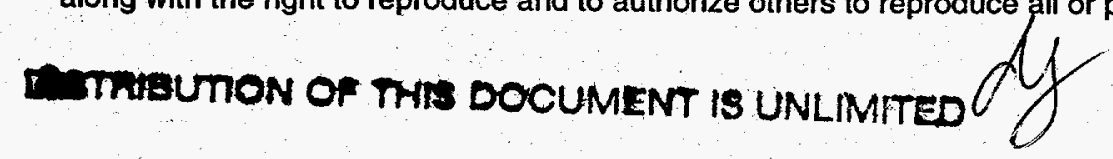




\section{RECOMMENDATIONS FOR THE USE OF INHIBITED WATER DURING PHASE I SALT DISSOLUTION IN TANK 41(U)}

\section{B. J. Wiersma}

Savannah River Technology Center Applied Science and Engineering Technology Department Materials Technology Section

Publication Date: January, 1996

\section{Westinghouse Savannah River Company Savannah River Site Aiken, SC 29808}

This document was prepared in connection with work done under Contract No. DE-AC09-89SR18035 with the U. S. Department of Energy. By acceptance of this document, the publisher and/or recipient acknowledges the U. S. Government's right to retain a nonexclusive, royalty-free license in and to any copyright covering this document, along with the right to reproduce and authorize others to reproduce all or part of the copyrighted material. 


\section{DISCLAIMER}

This report was prepared as an account of work sponsored by an agency of the United States Government. Neither the United States Government nor any agency thereof, nor any of their employees, makes any warranty, express or implied, or assumes any legal liability or responsibility for the accuracy, completeness, or usefulness of any information, apparatus, product, or process disclosed, or represents that its use would not infringe privately owned rights. Reference herein to any specific commercial product, process, or service by trade name, trademark, manufacturer, or otherwise does not necessarily constitute or imply its endorsement, recommendation, or favoring by the United States Government or any agency thereof. The views and opinions of authors expressed herein do not necessarily state or reflect those of the United States Government or any agency thereof.

This report has been reproduced directly from the best available copy.

Available to DOE and DOE contractors from the Office of Scientific and Technical Information, P.O. Box 62, Oak Ridge, TN 37831; prices available from (615) 576-8401.

Available to the public from the National Technical Information Service, U.S. Department of Commerce; 5285 Port Royal Road, Springfield, VA 22161. 


\section{DISCLAIMER}

Portions of this document may be illegible electronic image products. Images are produced from the best available original document. 


\title{
ASET
}

APPLIED SCIENCE \& ENGINEERING TECHNOLOGY

Keywords: Waste Tanks, stress corrosion cracking, saltcake

Retention - Permanent

\section{Recommendations for the Use of Inhibited Water During Phase I Salt Dissolution in Tank 41 (U)}

\author{
by
}

B. J. Wiersma

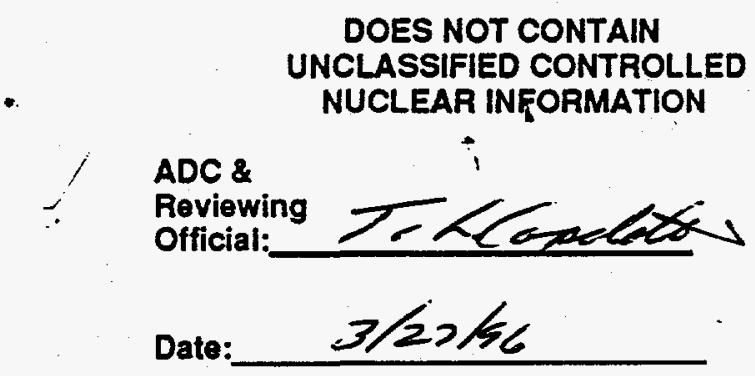

SRTC SAVANNAH RIVER TEChNOLOGY CENTER, AIKEN, SC 29808 Westinghouse Savannah River Company

Prepared for the U. S. Department of Energy under Contract DE-AC09-89SR18035 


\section{TABLE OF CONTENTS}

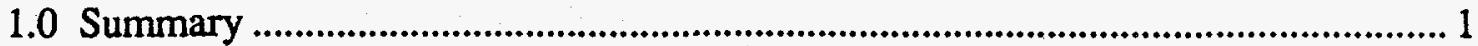

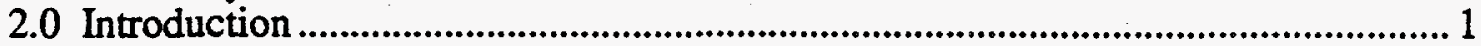

3.0 Experimental Apparatus and Procedure ....................................................................... 2

4.0 Experimental Results .................................................................................................. 2

5.0 Material Balance Model ................................................................................................. 3

6.0 Application of Results and Model to Phase 1 Salt Removal .................................... 4

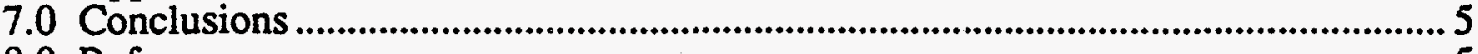

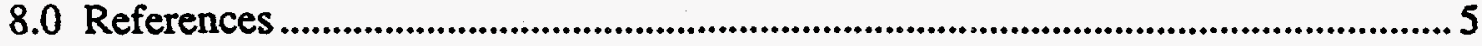

\section{LIST OF TABLES}

Table 3.1 Composition of Salt Solids in Laboratory Test and Tank 41 in wt.\% ............ 6 Table 4.1 Compositions of Solutions During the Laboratory Simulation and Tank

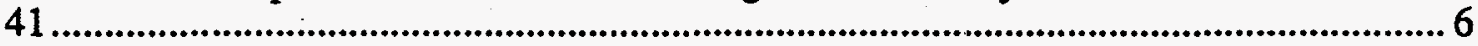
Table 5.1 Results of Model for Laboratory Tests and Tank 41..................................... 6 6 
WSRC-TR-96-0085 (U)

APPROVALS

Dunce A. Nürama

Date: $3-26-96$

B. J. Wiersma, AUTHOR

Materials Applications \& Corrosion Technology Group

MATERIALS TECHNOLOGY SECTION

Gel. Mückalomis

Date: $3 / 26 / 96$

. I. Mickalonis, TECHNICAL REVIEWER

Materials Applications \& Corrosion Technology Group MATERIALS TECHNOLOGY SECTION

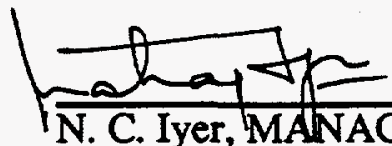

Date: $3 / 26 / 96$

Materials Applications \& Corrosion Technology Group MATERIALS TECHNOLOGY SECTION

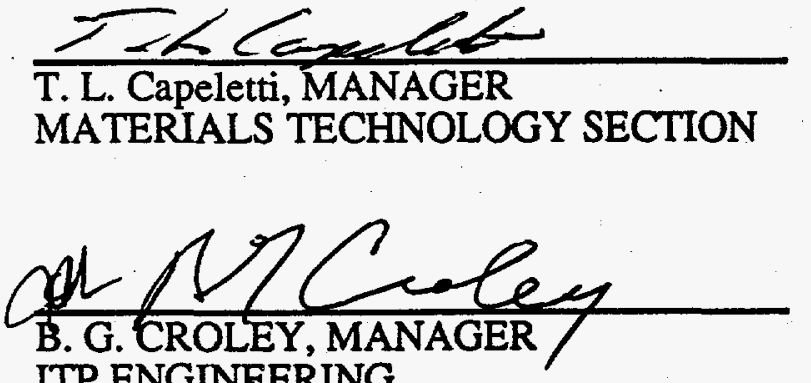

ISP ENGINEERING

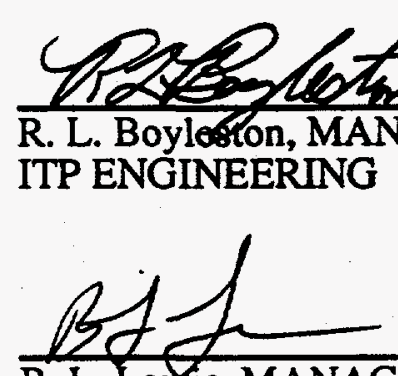

B. L. Lewis, MANAGER

Engineering Support

HIGH-LEVEL WASTE ENGINEERING
Date: $3 / 22 / 46$

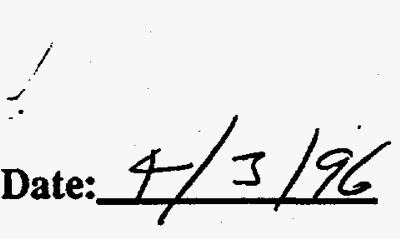

Date: $4 / 22 / 96$

Date: $4 / 22 / 96$ 
Recommendations for the Use of Inhibited Water During Phase I Salt Dissolution in Tank 41 (U)

\subsection{Summary}

A procedure for Phase 1 salt removal from Tank 41 using inhibited water $(0.01 \mathrm{M}$ sodium hydroxide and $0.011 \mathrm{M}$ sodium nitrite) was recommended. The use of inhibited water for this phase of dissolution is valid for the first batch of dissolution water that is added. The steps in the procedure are as follows:

1) Locate a bubbler dip tube at the desired level determined by the criticality analysis.

2) Remove the seven inches of supernate that is above the saltcake and continue pumping until the bubbler dip tube indicates that the liquid is below the desired level.

3) Measure the total liquid that was pumped out. Subtract the amount of supernate that was removed to calculate the amount of interstitial liquid that was removed.

4) Add a volume of dissolution water that is equivalent to the amount of interstitial liquid removed. Approximately 1 gallon of salt will be removed for every 1.4 gallons of dissolution water that is added.

The bases for these recommendations are laboratory tests on simulated salt and a material balance model. This procedure allows utilization of inhibited water as the dissolution water, while producing a salt solution that remains within the corrosion technical standards. Entrapped interstitial liquid, which is high in hydroxide is very beneficial in this process. As salt dissolution continues, the interstitial liquid will be displaced, and the salt solution removed will be outside the current technical standards. Therefore other alternatives to this procedure.will be necessary for subsequent phases.

\subsection{Introduction}

The saltcake in Tank 41 will be utilized to demonstrate yarious methods for sali dissolution [1]. Of particular interest are techniques which utilize density gradients that occur as the salt is dissolving. The salt solutions which are produced during these methods are required to remain within the current corrosion technical standards [2]. The salt which is being dissolved has a characteristically high nitrate concentration (corrosive species to carbon steel) relative to hydroxide and nitrite concentrations. The issue is whether or not inhibited water may be added as the dissolution water and still produce a salt solution which is within the corrosion technical standards.

Phase 1 of the testing will remove 3-4 feet of the saltcake. At this point operations would be suspended to resolve any criticality issues. Waste Removal desires a procedure which will utilize inhibited water ( $0.01 \mathrm{M}$ sodium hydroxide and $0.011 \mathrm{M}$ sodium nitrite) as the dissolution water and still maintain the salt solution that is produced within the corrosion technical standards. Laboratory tests and a material balance model were utilized to justify this approach. 


\subsection{Experimental Apparatus and Procedure}

The initial salt dissolution tests were performed in a four foot high, two and a half inch diameter, Pyrex ${ }^{\mathrm{TM}}$ cylinder. A spigot with a stopcock was located at the bottom of the cylinder to drain solution from the saltcake within the cylinder. The saltcake was prepared with sodium salts to simulate the composition of the Tank 41 saltcake [3]. The sodium salts were initially dissolved in approximately 1.5 liters of distilled water. The solution was then evaporated to approximately one half the original volume. The resulting slurry was then poured into the cylinder and allowed to cool overnight. This sequence was repeated until approximately 3.6 liters of saltcake had formed in the cylinder. The composition of the saltcake solids, as well as the composition of the Tank 41 saltcake solids, are shown in Table 3.1.

The initial step in the dissolution procedure was to drain the interstitial liquid in the saltcake by gravity through the spigot. This process occurred over a 72 hour period. Dissolution water, with a composition of $0.01 \mathrm{M}$ sodium hydroxide and $0.011 \mathrm{M}$ sodium nitrite, was added to the cylinder slowly until the liquid level was even with the top of the saltcake. The saltcake/dissolution water mixture was allowed to stand for approximately 24 hours. During this period significant dissolution occurred resulting in the liquid level being above the top of the saltcake. The solution was then completely drained from the saltcake by gravity. The sequence was repeated until the saltcake was dissolved.

The pertinent data obtained from this test included: the amount of interstitial liquid drained, the composition of the interstitial liquid, the amount of dissolution water added, the composition of the dissolution water, the composition of the saltcake solids, the amount of salt solution removed, and the composition of the salt solution removed. The results of these tests are being verified by experiments that are being performed in a rectangular trough [4].

\subsection{Experimental Results}

The initial volume of saltcake, including the interstitial liquid, was $3575 \mathrm{ml}$. After the 72 hour draining period, during which $1040 \mathrm{ml}$ of interstitial liquid was removed, this saltcake had slumped to $3510 \mathrm{ml}$. The composition of the interstitial liquid is shown in Table 4.1. Visual observation of the column indicated that interstitial liquid remained entrapped and dispersed throughout the saltcake. The surface tension between the liquid and the crystals entrap the solution in small pores. A visual estimate was made that the saltcake contained 5-10 vol.\% liquid (or approximately $10-30 \%$ of the initial interstitial liquid volume). The quantity of dissolution water added was $1080 \mathrm{ml}$ or approximately the same as the amount of interstitial liquid that was drained from the saltcake. After standing for 24 hours, $1730 \mathrm{ml}$ of salt solution was drained from the saltcake. The increase in volume of the dissolution water is due to the dissolution of salt and blending in of the interstitial liquid. The composition of the salt solution that was removed is also shown in Table 4.1. Both the interstitial liquid and the initial salt solution were within the current corrosion technical standards.

Three subsequent batches of dissolution water were added to the cylinder. The composition of the salt solution removed after each batch is also shown in Table 4.1. These compositions were not within the cortosion technical standards. The first test probably benefited from the presence of the entrapped interstitial liquid. After the first test, most of the interstitial liquid had been removed and for the remaining tests the salt, which is very concentrated with sodium nitrate relative to sodium nitrite and sodium hydroxide, was being dissolved by water with a very dilute inhibitor concentration. In order to maintain, the salt solution with in the current corrosion technical standards for 
the final three batches it would have been necessary to add dissolution water inhibited with $1 \mathrm{M}$ sodium hydroxide.

\subsection{Material Balance Model}

A material balance model was derived to explain the results from the column tests. The following results and assumptions were utilized in the material balance model:

a) The entrapped interstitial liquid is homogeneously dispersed in the saltcake.

b) Volumes are approximately additive.

c) The saltcake initially contains $38-50$ vol.\% interstitial liquid.

d) After draining the interstitial liquid, 10-30 vol. \% of the initial interstitial liquid remains entrapped in the saltcake.

e) The volume of dissolution water added is equal to the volume of interstitial liquid drained from the saltcake.

f) The volume of salt solution removed from the cylinder is 1.7 times the amount of dissolution water added.

The material balance for a component is represented by the following equation:

$$
\mathrm{C}_{\mathrm{i}} \mathrm{V}_{\mathrm{i}}+\mathrm{C}_{\mathrm{dw}} \mathrm{V}_{\mathrm{dw}}+\mathrm{C}_{\mathrm{s}} \mathrm{V}_{\mathrm{s}}=\mathrm{C}_{\mathrm{f}} \mathrm{V}_{\mathrm{f}}
$$

where $\mathrm{C}$ represents the molar concentration of the component, $\mathrm{V}$ is the volume in liters, the subscript $\mathrm{i}$ refers to the interstitial liquid, the subscript $\mathrm{dw}$ refers to the dissolution water, the subscript $s$ refers to the saltcake solids, and the subscript $f$ refers to the final salt solution. The following relationships were derived from the results and assumptions in order to simplify the equation.

a) The volume of dissolution water added equals the tolume of interstitial liquid drained.

$$
\mathrm{V}_{\mathrm{dw}}=\mathrm{V}_{\mathrm{d}}=(1-\mathrm{x}) \mathrm{V}_{\mathrm{io}}
$$

where $\mathrm{x}$ is the fraction of the initial interstitial liquid that remains entrapped in the saltcake, the subscript $d$ refers to the volume of interstitial liquid drained, and the subscript io refers to the initial volume of interstitial liquid.

b) The volume of interstitial liquid, $\mathrm{Vi}$, that is entrapped in the saltcake is some fraction, $x$, of the initial interstitial liquid.

$$
\mathrm{V}_{\mathrm{i}}=\mathrm{x} \mathrm{V}_{\mathrm{io}}
$$

c) The volume of solids dissolved and interstitial liquid removed is 0.7 times the dissolution water that was added. Therefore, in terms of the initial volume of interstitial liquid, the volume of salt solids dissolved is given by:

$$
\mathrm{V}_{\mathrm{S}}=0.7(1-\mathrm{x}) \mathrm{V}_{\text {io }}-\mathrm{x} \text { if }
$$


d) The final volume of salt solution removed, $\mathrm{V}_{\mathrm{f}}$, is 1.7 times the amount of dissolution water added. In terms of the initial volume of interstitial liquid, the final volume of salt is:

$$
\mathrm{V}_{\mathrm{f}}=1.7(1-\mathrm{x}) \mathrm{V}_{\text {io }}
$$

Equations 2-5 were substituted into Equation 1 and solved for $\mathrm{C}_{\mathrm{f}}$ in terms of the fraction of interstitial liquid and the concentrations of the component in the dissolution water, the saltcake solids and the interstitial liquid.

$$
C_{f}=\frac{x C_{i}+(1-x) C_{d w}+(0.7-1.7 x) C_{S}}{1.7(1-x)}
$$

This equation was solved on an EXCEL ${ }^{\mathrm{TM}}$ spreadsheet for $\mathrm{x}$ at 0.1 and 0.3 . The results are shown in Table 5.1. The results assuming 10-30\% of the initial interstitial liquid remaining bracket the composition of the actual salt solution removed very well (see Table 4.1).

\subsection{Application of Results and Model to Phase 1 Salt Removal}

The sequence for salt dissolution performed in the cylinder should allow one to utilize inhibited water $(0.01 \mathrm{M}$ sodium hydroxide and $0.011 \mathrm{M}$ sodium nitrite) during Phase 1 of salt removal. During Phase 1 four to five feet of salt will be removed before the process will be halted to resolve criticality issues. The following steps are recommended:

1) Locate a bubbler dip tube at the desired level, say four feet below the surface of the salt.

2) Remove the seven inches of supernate that is above the salt cake $(-25,000$ gallons) and continue pumping until the bubbler dip tube indicates that the liquid level is below four to five feet. Given that the vol. \% interstitial liquid can be estimated to be 38 , the fraction of interstitial liquid removed is 0.7 , and that there is approximately 3500 , gallons/inch, it is estimated that approximately 44,500 gallons of liquid would be removed from four feet of salt. Therefore the total liquid removed would be 69,500 gallons

3) Measure the total liquid that was actually removed. Subtract the amount of supernate that was removed $(\sim 25,000$ gallons) to calculate the amount of interstitial liquid that was removed.

4) Add a volume of dissolution water that is equivalent to the amount of interstitial liquid removed. The salt solution removed will be approximately 1.7 times the amount of dissolution water added. For the four foot salt removal example, approximately 76,000 gallons of salt solution will be removed. Typically engineering and operations personnel have used the ratio of the gallons of dissolution water to remove 1 gallon of salt as an indicator of the efficiency of the salt removal process [5]. Conversion of the previous 1.7 ratio to the more familiar ratio predicts that approximately 1.4 gallons of dissolution water will dissolve 1 gallon of salt. Therefore, the amount of salt removed is estimated to be 31,000 gallons.

Two aspects need to be considered when comparing the actual tank to the cylinder experiments. First, the pump may not be able to draw off $70 \%$ of the interstitial liquid. 
The fraction may be something like $50 \%$. In one sense this is beneficial in that there is more interstitial liquid available to inhibit the salt solution. On the other hand less salt will be dissolved. The other aspect to consider is that the interstitial liquid in Tank 41 has a higher hydroxide and nitrite concentration than the laboratory tests (see Table 4.1). Assuming $70 \%$ of the interstitial liquid is removed the same material balance model was utilized to calculate the composition of the salt solution removed. Table 5.1 indicates that the salt solution formed would be well above the current corrosion technical standards.

\subsection{Conclusions}

A procedure was recommended for Phase 1 removal of saltcake from Tank 41 using inhibited water. The procedure is based on results from laboratory testing and a material balance model. Although this procedure will work initially, as more of the interstitial liquid is removed the salt solution will eventually fall outside the current technical standards. A program is underway to examine the suitability of modifying the current technical standards for waste removal applications.

\subsection{References}

1. S. C. Lee and W. E. Perry, "Test Plan for Tank 41 Salt Dissolution - Phäse I", HLW-ITP-950638, January 1996.

2. Technical Standard: Waste Tank Farms, DPSTS-241-5.01, November, 1988.

3. D. T. Hobbs and C. J. Coleman, "Final Report: Analysis of Tank 41H Saltcake Sample \#2 and Comparison to Sample \#1 (U)", WSRC-TR-94-057, January 26, 1994.

4. B. J. Wiersma, "Plan for Simulation of Salt Dissolution Demonstration and Recommendations for Corrosion Control During Waste Removal Operations (U)", WSRC-TR-96-0020, January, 1996.

5. A. Q. Goslen, "Tank 19 Salt Removal", DPŞP-84-17-7, August 1986. 
Table 3.1 Composition of Salt Solids in Laboratory Test and Tank 41 in wt.\%

Anion
Nitrate
Nitrite
Hydroxide
Carbonate
Phosphate
Sulfate
Oxalate

\begin{tabular}{c} 
Laboratory Test \\
\hline 69.2 \\
1.18 \\
5.42 \\
18.8 \\
3.0 \\
1.9 \\
0.6
\end{tabular}

\begin{tabular}{c} 
Tank 41 \\
\hline 70 \\
1.7 \\
3.44 \\
19.4 \\
1.2 \\
2.1 \\
0.3
\end{tabular}

Table 4.1 Compositions of Solutions During the Laboratory Simulation and Tank 41

\begin{tabular}{ccccccc} 
Anion & $\begin{array}{c}\text { Interstitial } \\
\text { Liquid } \\
\text { Laboratory }\end{array}$ & $\begin{array}{c}\text { Interstitial } \\
\text { Liquid Tank 41 } \\
\text { (Feb. '96) }\end{array}$ & Batch 1 & Batch 2 & Batch 3 & Batch 4 \\
\hline Nitrate & 4.05 & 1.93 & 5.03 & 5.96 & 6.01 & 5.16 \\
Nitrite & 0.38 & 1.2 & 0.24 & 0.05 & 0.01 & 0.01 \\
Hydroxide & 2.12 & 6.39 & 1.11 & 0.16 & 0.025 & 0.023
\end{tabular}

Table 5.1 Results of Model for Laboratory Tests and Tank 41.

$\begin{array}{lllll}\text { Anion } & \text { Laboratory } & \text { Laboratory } & \text { Tank } 41 & \text { Tank } 41 \\ \text { Nitrate } & 4.98 & 8.85 & 4.53 & 8.74 \\ \text { Nitrite } & 0.23 & 0.31 & 0.47 & 0.37 \\ \text { Hydroxide } & 1.25 & 1.68 & 2.42 & 1.99 \\ \text { Fraction } & 0.3 & 0.1 & 0.3 & 0.1\end{array}$


Distribution:

\begin{tabular}{|c|c|c|c|}
\hline $\begin{array}{l}\text { T. J. Lex, } \\
\text { H. D. Harmon } \\
\text { G. T. Wright, } \\
\text { M. D. Johnson, } \\
\text { B. G. Croley, } \\
\text { R. L. Boyleston, } \\
\text { W. R. Parish, } \\
\text { G. L. Cauthen, } \\
\text { W. B. Van Pelt, } \\
\text { A. P. Christensen, } \\
\text { B. J. Shapiro, } \\
\text { R. W. Cummings, } \\
\text { T. C. Temple, } \\
\text { S. D. Fink, } \\
\text { J. D. Cohen, } \\
\text { N. C. Iyer, } \\
\text { P. E. Zapp, } \\
\text { ITP Files, } \\
\text { HLWE Files, } \\
\text { MTS Files, }\end{array}$ & $\begin{array}{l}719-4 \mathrm{~A} \\
719-4 \mathrm{~A} \\
703-\mathrm{H} \\
704-56 \mathrm{H} \\
241-120 \mathrm{H} \\
706-23 \mathrm{C} \\
703-8 \mathrm{C} \\
241-119 \mathrm{H} \\
676-1 \mathrm{~T} \\
241-121 \mathrm{H} \\
992-1 \mathrm{~W} \\
241-121 \mathrm{H} \\
\text { DOE,703-H } \\
773-\mathrm{A} \\
773-\mathrm{A} \\
773-\mathrm{A} \\
773-\mathrm{A} \\
704-56 \mathrm{H} \\
703-\mathrm{H} \\
773-\mathrm{A}\end{array}$ & $\begin{array}{l}\text { T. M. Monahon, } \\
\text { W. B. Boore, } \\
\text { D. R. Buchanan, } \\
\text { J. E. Marra, } \\
\text { B. L. Lewis, } \\
\text { W. C. Clark, } \\
\text { G. D. Thaxton, } \\
\text { T. L. Ortner, } \\
\text { S. C. Lee, } \\
\text { R. M. Satterfield, } \\
\text { G. L. Jager, } \\
\text { J. L. O'Conner, } \\
\text { W. L. Tamosaitis, } \\
\text { D. T. Hobbs, } \\
\text { T. L. Capeletti, } \\
\text { J. I. Mickalonis, }\end{array}$ & $\begin{array}{l}703-\mathrm{H} \\
703-8 \mathrm{C} \\
704-6 \mathrm{C} \\
241-120 \mathrm{H} \\
703-8 \mathrm{C} \\
241-119 \mathrm{H} \\
241-119 \mathrm{H} \\
241-152 \mathrm{H} \\
730-\mathrm{B} \\
719-4 \mathrm{~A} \\
705-\mathrm{C} \\
\text { DOE, } 241-120 \mathrm{H} \\
773-\mathrm{A} \\
-773-\mathrm{A} \\
-773-41 \mathrm{~A} \\
-773-\mathrm{A}\end{array}$ \\
\hline
\end{tabular}

